\title{
Artículo Especial: Obras maestras del arte universal y la medicina: "Pigmalión" de George Bernard Shaw (1856 -1950)
}

\author{
Universal Art Masterpieces and Medicine: Pygmalion by George Bernard Shaw
}

Carlos Musso*

"Los espejos se emplean para verse la cara; el arte para verse el alma."

George Bernard Shaw

\begin{abstract}
Argumento
Henry Higgins era un solterón británico estudioso de la fonética, la cual constituía para él no sólo su pasión sino también su fuente de subsistencia, pues su trabajo consistía en dar lecciones de pronunciación a ricos burgueses que deseaban relacionarse con aristócratas sin que su habla los pusiese en evidencia. Un día, Higgins recorría las calles londinenses junto a su amigo el Coronel Pickering cuando conoció a una joven florista (Liza Doolittle) la cual se expresaba en un verdadero "inglés de albañal". Higgins alardeó frente a la muchacha y su amigo, que podría transformar a la humilde florista en toda una dama en tan sólo seis meses. Liza, que inmediatamente vio en ello la oportunidad de progresar socialmente, le pidió al fonetista que la tomara como alumna. Higgins accedió a su pedido, que lo atraía como un verdadero "experimento fonético", que además devino una apuesta entre ambos amigos. Liza se mudó a la casa de Higgins, quien junto a su ama de llaves y Pickering comenzaron la ardua tarea de reeducar a Liza. Sólo la madre de Higgins les advirtió del peligro que significaba realizar la transfomación de Liza sin preocuparse por su futura inserción social, pues podría quedar peligrosamente atrapada entre dos mundos, sin llegar a pertenecer del todo a ninguno de ellos. Cuando llegó el día de la prueba final, Liza fue llevada por Higgins y Pickering a una recepción de gala en una embajada de Londres, donde la muchacha se convirtió por su exquisita belleza, refinados modales y prolija expresión en el centro de atención de la velada. De regreso a su casa Higgins y Pickering celebraron su triunfo mientras que Liza sintió que había sido tan sólo objeto de un juego, y que en realidad nadie había pensado en ella como en un ser humano. Luego de recriminarle estos planteos a su maestro y de discutir con él, alumna y profesor hicieron las paces, tras llegar a comprender que sus vidas se habían entrelazado definitivamente.
\end{abstract}

\section{Ejemplo en el texto:}

“...pero no tienes idea de cuán espantosamente interesante es tomar a un ser humano y convertirlo en otro ser humano completamente distinto con sólo crearle un nuevo idioma"

\section{Análisis del texto}

El título de esta obra remite a una famosa historia de la mitología griega relatada por Ovidio en el capítulo $X$ de su obra Las Metamorfosis: Pigmalión era un rey que poseía dotes de eximio escultor, y que después de mucho tiempo de haber buscado infructuosamente una mujer cuya belleza correspondiera a su ideal femenino, había decidido permanecer soltero y crear una estatua que representara a su mujer ideal. Pigmalión esculpió entonces una mujer de extrema belleza, a la que dio el nombre de Galatea y de la cual se enamoró perdidamente. Fue entonces que Afrodita, la diosa del amor, conmovida por esta situación le dijo a Pigmalión: “....mereces la felicidad que tu mismo has creado...", tras lo cual dio vida a la estatua, a quien luego el escultor desposó.

Ambos relatos de "Pigmalion", el clásico y el escrito por Bernard Shaw nos hablan del poder, tanto positivo como negativo, de la fuerza del deseo.

En esta obra se encuentra ejemplificado el concepto de la profecía auto-cumplida o efecto pigmalión: aquello que se anuncia "proféticamente" termina sucediendo por haberse promovido en múltiples oportunidades situaciones favorecedoras o desfavorecedoras (según el sentido positivo o negativo de lo anunciado) en pos de su concreción.

Su polaridad positiva (pigmalión positivo) esta representada en la práctica médica por aquellas situaciones en las que el terapeuta cree que su paciente tiene posibilidades de superar su problema, y entonces se esfuerza en que así sea: explicándole claramente su situación, logrando que acceda a hacerse los estudios diagnósticos y esquemas terapéuticos necesarios, etc. Por el contrario, su polaridad negativa (pigmalión negativo) está representado por una actitud opuesta a la anterior. Recordemos que no hay cuestiones agotadas (pacientes sin tratamiento posible) sino hombres (médicos) agotados en las cuestiones. La sombra del pigmalión negativo se resume en la nefasta frase “...no hay más nada que hacer...". Si el médico nota que es víctima del efecto de un pigmalión negativo, debe propiciar un cambio de perspectiva del problema ya sea realizándose un replanteo radical del mismo o consultando oportunamente a sus colegas.

El efecto pigmalión es el responsable además de una de la situaciones más frecuentes de la medicina asistencial: el médico al enamorarse de sus conjeturas diagnósticas, fenómeno positivo desde el momento que lo estimula a buscar información que las avale, debe sin embargo evitar que el afán de querer dar categoría de tesis a sus hipótesis lo lleve inconscientemente a jerarquizar los datos que sean favorables a ella y a desestimar aquellos que la ponen en duda, forjando así un diagnóstico a su medida, en vez de hacerlo a la de la realidad. Recordemos que como decía Lacan, el diagnóstico de certeza de una enfermedad siempre viene después de su tratamiento, hasta entonces no es más que una mera conjetura.

\section{Conclusión}

La obra de teatro Pigmalión de George Bernard Shaw constituye una excelente oportunidad para reflexionar acerca del grado de influencia de nuestro parecer en el curso evolutivo de nuestros pacientes.

Bibliografía recomendada

- Amalfi F. El taller de los escritores. Barcelona. Editorial Océano. 2005

- Asquith A, Howard L. Pygmallion 1938 (film).

- Bernard Shaw G. Pigmalión. Buenos Aires. Centro Editor de América Latina. 1980

- Cukor G. My fair lady. 1964 (film)

- Ovidio. Las metamorfosis. Barcelona. Fontana.1995. 